\title{
Henry A. Kissinger as Negotiator: Background and Key Accomplishments
}

\section{Citation}

Sebenius, James K., and Laurence A. Green. "Henry A. Kissinger as Negotiator: Background and Key Accomplishments." Harvard Business School Working Paper, No. 15-040, November 2014. (Revised December 2014.)

\section{Permanent link}

http://nrs.harvard.edu/urn-3:HUL.InstRepos:13479072

\section{Terms of Use}

This article was downloaded from Harvard University's DASH repository, and is made available under the terms and conditions applicable to Open Access Policy Articles, as set forth at http:// nrs.harvard.edu/urn-3:HUL.InstRepos:dash.current.terms-of-use\#OAP

\section{Share Your Story}

The Harvard community has made this article openly available.

Please share how this access benefits you. Submit a story.

Accessibility 


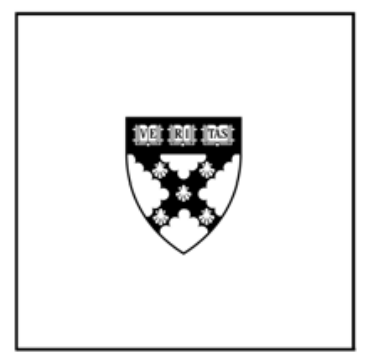

\title{
Henry A. Kissinger as Negotiator: Background and Key Accomplishments
}

\author{
James K. Sebenius \\ Laurence A. Green
}

\section{Working Paper}

15-040

December 23, 2014 


\title{
Henry A. Kissinger as Negotiator: Background and Key Accomplishments
}

\author{
James K. Sebenius and Laurence A. Green* \\ November 24, 2014, v1.0 rev. Dec. 23, 2014
}

\begin{abstract}
Following a brief summary of Henry A. Kissinger's career, this paper describes three of his most pivotal negotiations: the historic establishment of U.S. diplomatic relations with the People's Republic of China, the easing of geopolitical tension with the Soviet Union, symbolized by the signing of the first

Strategic Arms Limitation Treaty ("SALT I"), and the mediation of the agreement on Sinai disengagement between Egypt and Israel. An appendix lists other important negotiations in which Kissinger played key roles. In a subsequent paper (forthcoming), the authors will examine these and other major events in which Henry Kissinger played leading roles in order to extract their most important insights into the principles and practice of effective negotiation.
\end{abstract}

Keywords: Kissinger, negotiation, bargaining, diplomacy, multiparty negotiations, dispute resolution, mediation, international relations

Hosted in 2014 by the Harvard-based Program on Negotiation and the Future of Diplomacy Program's American Secretaries of State Project, Henry Kissinger is a statesman, scholar, and public intellectual. Born in 1923 to a German Jewish family in Fürth, Henry Kissinger emigrated from Germany to the United States in 1938 to avoid "state sanctioned anti-Semitism" by the Nazi government. ${ }^{1}$ He became a naturalized United States citizen in 1943 and served in the Army from 1943 to 1946. After completing his education at Harvard (BA summa cum laude 1950, M.A. 1952, and Ph.D. 1954), he served as a faculty member in Harvard's Department of Government and its Center for International Affairs from 1954 to $1969 .^{2}$ As an academic, two of his early books are widely regarded as pathbreaking both conceptually and for their policy implications: A World Restored: Metternich, Castlereagh and the Problems of Peace, 1812-22 (1957) and Nuclear Weapons and Foreign Policy (1957).

Kissinger served as foreign policy advisor to New York Governor Nelson Rockefeller, who three times sought the Republican nomination for President. ${ }^{3}$ Despite his support of Rockefeller, a political rival, President Richard Nixon selected Kissinger, a prominent advocate of realpolitik, to serve as his Advisor for National Security Affairs from January 20, 1969 to November 3, 1975. While National Security Advisor, Kissinger was also sworn in as the 56th Secretary of State on September 22, 1973.4 After the Watergate scandal led to Nixon's resignation, Kissinger continued to serve as Secretary of State under President Gerald Ford until January 20, 1977. In this role, he flew 565,000 miles, once visiting 17 countries in 18 days. ${ }^{5}$

Throughout his time as National Security Advisor and Secretary of State, Kissinger exerted a strong influence on American foreign policy. He took the lead in conceptualizing and implementing the policy of détente with the Soviet Union, intended to relax dangerous tensions between the two nuclear superpowers. ${ }^{6}$ As part of this process, he negotiated the Strategic Arms Limitation Talks (resulting in the SALT I treaty, elaborated below) and the Anti-Ballistic Missile Treaty.

- Copyright $@ 2014$ by James K. Sebenius. Special thanks to Cathryn Cluver and Eugene Kogan. Laurence A. Green and James K. Sebenius can be reached, respectively, at agreen.alex@gmail.com and jsebenius@hbs.edu. 
In tandem with working for détente with the Soviet Union, he played a central role (elaborated below) in helping to end 23 years of diplomatic isolation and mutual suspicion between the United States and China. Culminating in the 1972 summit among Richard Nixon, Chou (often transliterated as "Zhou") Enlai, and Mao Zedong, this initiative led to formal relations between the two countries, helped the United States make progress in extricating itself from Vietnam, and transformed U.S.Chinese-Soviet relations into a form of "triangular diplomacy."

By 1973, following prolonged secret negotiations between Kissinger and Le Duc Tho, North Vietnamese politburo member, the Paris Peace Accords were signed. Intended to end the Vietnam war, this agreement led to a (temporary) ceasefire and was followed by the cessation of direct U.S. military involvement - though its major provisions were never implemented as intended.

Following the October 1973 Yom Kippur war among Israel, Egypt, and Syria, Kissinger engaged in an intensive process of "shuttle diplomacy." His efforts over eight days in January 1974 led to an initial Egyptian-Israeli disengagement accord, followed by a Syrian-Israeli disengagement in May of that year, and a second Egyptian-Israeli disengagement agreement in September 1975.

Involved in many other foreign policy initiatives and negotiations, some of which are briefly described in the appendix of this paper, Dr. Kissinger received the Nobel Peace Prize in 1973 for his work on the Paris Peace Accords. ${ }^{7}$ Among other awards he has received are the Presidential Medal of Freedom in 1977 and the Medal of Liberty in 1986. Since leaving office, Kissinger has served as Chairman of Kissinger Associates, a strategy consulting firm, and has been in demand publicly and by a range of national leaders around the globe for his analysis and advice on challenging foreign policy issues. ${ }^{8}$

A prolific author of 21 books and many articles, he is especially notable for his three-volume set of memoirs that chronicle his time in office, the first volume of which, White House Years, won the National Book Award. ${ }^{9}$ These volumes contain invaluable and detailed discussions of the many negotiations in which Kissinger was involved. His 1994 book, Diplomacy, offers a panoramic view of international relations, negotiations, and diplomacy, with special concentrations on the $20^{\text {th }}$ century and the West. The book articulates Kissinger's realist orientation, argues for the importance of the balance of power and the concept of "national interest," and critiques both the practice of "collective security" and an overly idealistic foreign policy. ${ }^{10}$ From a realist perspective, On China (2011) examines Chinese history and Kissinger's own experience with a forward look especially at U.S.Chinese relations. ${ }^{11}$ Most recently World Order (2014), published in Kissinger's $91^{\text {st }}$ year, offers a far more global and historical perspective on his traditional themes. This latest book explores the evolution, interaction, and possible futures of four "world order" conceptions. These include the Westphalian model, originating in Europe, of nominally equal sovereign states; the Chinese system envisioning the Middle Kingdom at its center with outlying tributary states; an expansive Islamic idea of a world community or ummah; and an American order heavily informed by the supposedly universal ideals articulated by Woodrow Wilson that both dominates the world and is under siege from many quarters. ${ }^{12}$

To offer a more granular sense of Kissinger as statesman, diplomat, and negotiator, the following sections will look in more depth at three key negotiations that took place within Kissinger's overarching conception of statecraft and world order. These include the opening to China, SALT I in the context of détente, and Sinai disengagement. In a subsequent paper (forthcoming), the authors 
Henry A. Kissinger as Negotiator

will examine these and other major events in which Henry Kissinger played leading roles in order to extract their most important insights into the principles and practice of effective negotiation. 


\section{Opening to China (1969-72)}

On July 9, 1971, Henry Kissinger stepped off of a plane borrowed from the president of Pakistan, onto the tarmac in Beijing. ${ }^{13}$ Arriving in secret, the first senior American official to engage in talks with the Chinese government in two decades, he was greeted with warmth and hospitality, and taken to the State Guesthouse to await the arrival of Premier Chou Enlai. ${ }^{14}$ It was a far cry from the initial attempts at fostering negotiations between the United States and China, which had broken off formal relations from one another a generation earlier. The two nations' delegates had been so isolated from one another for so long that an American diplomat's (authorized) attempt at outreach caused his panicked Chinese counterpart to flee a fashion show, pursued by the American, who shouted his hope to establish a channel for high-level talks on behalf of the President of the United States. ${ }^{15}$

By the time Kissinger became Richard Nixon's National Security Advisor in January 1969, the United States had been engaged in largely formulaic talks with People's Republic of China (PRC) for a number of years. ${ }^{16}$ In over 134 sessions periodically held in Warsaw, U.S. support for an independent Taiwan, vehemently opposed by China, was publicly declared to be the reason for both sides' entrenchment. Over time the talks had devolved to the statement and re-statement of unchanging positions on both sides.

An array of significant issues compounded and exacerbated the isolation of one nation from the other. The United States ideologically opposed the Communist leadership of China, and believed that the PRC was intent on spreading communism across the region. American leaders found affirmation for this suspicion in Chinese support for the North Vietnamese regime, whose resistance to the American-supported South Vietnam had resulted in a military quagmire that caused growing domestic instability in the United States. The Cultural Revolution, a series of violent social and political policies implemented by PRC Chairman Mao Zedong further fed American fears that the Chinese leadership would sacrifice millions of its own people-and consequently people of other nations - to impose its vision of communism on the world.

In the Americans, Beijing saw an equally ideologically driven opponent, willing to undertake brutal means to achieve its ends. Mao, Chou, and other PRC leaders found support for their beliefs in the Vietnamese conflict, which they related to the Korean War that had led to the rupture in diplomatic ties between the two nations in the early 1950s. ${ }^{17}$

Yet the Americans did not know the full extent to which relations between the PRC and the Union of Soviet Socialist Republics (USSR) had been deteriorating, and this widening Sino-Soviet rift proved fateful for a thaw in relations. Both Communist in ideology, the PRC and USSR comprised a formidable alliance in opposition to the United States, but relations between the two nations had begun to worsen in the early 1960s. The Soviet invasion of Czechoslovakia in August 1968, which caused serious concern in the United States, also outraged the PRC, which believed it signaled the beginning of Soviet aggression against fellow communist nations. Soviet justification for the move, announced in November 1968 as the "Brezhnev Doctrine," further confirmed Chinese suspicions by formally asserting the Soviet Union's right to intervene in Communist countries in order to suppress opposition movements. ${ }^{18}$

Suspicion exploded into outright conflict when skirmishes broke out between Chinese and Soviet forces along the Ussuri River in Siberia from March to May 1969. Tensions escalated further when the Chinese counterattacked to signal that it would defend its borders. Intended to warn the Soviets off, the move resulted in the complete opposite effect. The largest two Communist countries in the 
world were now locked in a military standoff-some 658,000 Soviet troops confronted 814,000 Chinese troops along the border - that led to clashes with significant casualties on both sides. ${ }^{19}$

Pressured to declare an American stance on the Sino-Soviet split, Kissinger and Nixon reflected on the right policy, should the conflict widen between the two countries. Paramount among their objectives was constraining the expansion of Soviet influence. To that end, Kissinger and Nixon supported leaning in favor of the Chinese, something Nixon had already largely favored.

Little did they know that Mao was simultaneously attempting to signal a willingness to negotiate a significant thaw in relations between the two nations, which had often mainly consisted in insults hurled at each other. Taking stock of the geopolitical situation, Mao feared that only a few shifts in the international order could result in war on nearly every one of China's borders. He looked to the United States as a potential ally, and like his American counterparts, believed that a substantive, public agreement would offset the significant pressures against his regime, especially from the Soviets. In September 1969, Mao's advisors produced a report confirming this position and suggesting that despite its outward hostility toward Beijing, the United States would not want to see China destroyed in a Sino-Soviet war because it would result in accumulation of geopolitical power in Moscow.

In the context of these barriers, the two sides warily and somewhat blindly approached one another. Overly subtle and occasionally dismissed too hastily, Chinese overtures to the Americans often went unnoticed. American attempts, as the Warsaw fashion show revealed, were unsuccessful, and the Warsaw talk channel collapsed as a useful conduit not long after. ${ }^{20}$ Kissinger realized that a limited number of secure interlocutors were needed for relaying a more overt message to the Chinese leadership. He quickly identified Romania, a communist country, and Pakistan as ideal nations through which to send messages. Neither nation was aligned with the United States, but both also had some contact with China and would not be seen as unconditional Soviet allies. In a series of preliminary exchanges, the United States communicated through Romania and Pakistan, and the PRC replied through Norway and Afghanistan. ${ }^{21}$ Within a matter of months, a message came through from Premier Chou, inviting the United States to send a representative to Beijing. A subsequent message conveyed an invitation to Nixon. Chou wished to discuss Taiwan, but Nixon and Kissinger read more into his letter. ${ }^{22}$

They replied, testing to see if Chou would be open to a broader agenda and received positive signs. Seeing the need for absolute secrecy, and fearful of the ideological objections of Secretary of State William Rogers and a range of likely domestic opponents, Kissinger boarded a plane in early July with a handful of aides and Secret Service agents, and set off on a routine diplomatic mission that would end in Pakistan. ${ }^{23}$ At each stop the press lost interest in their mission, until the party, only some of whom knew more than part of what was up, could quietly board the president of Pakistan's plane and slip into China on July $9 .{ }^{24}$

Meeting with Chou, he swiftly abandoned his prevailing assumption of Chinese hostility as his counterparts made great efforts to put him at ease. Initially concerned by the lack of scheduled time for negotiations, Kissinger realized that Mao and Chou's approach was not meant to placate him, but rather to signal a willingness to learn more about each other, especially fundamental views of the international system, after many years without direct communication.

In the formal negotiating sessions that followed, Kissinger and Chou discussed the two most pressing issues-Taiwan and Vietnam-but in terms favorable to both. Kissinger found an easy 
counterpart in Chou. Both negotiated their most important issues largely by talking around them, linking them to major priorities they both knew to be most significant. Kissinger tested Chou's desire to negotiate matters other than Taiwan, and received a favorable reply. Chou would negotiate Taiwan, but was not concerned by the order in which it would be negotiated. Other issues could come first. Kissinger saw an opportunity to link concessions on Vietnam to concessions on Taiwan, dubbing Chou's position, "linkage in reverse." 25

As his visit came to a close, Kissinger drafted an agreement with Chou, to be announced by the leaders of both nations. Knowing of Nixon's longstanding interest in China, Mao would extend an offer for a state visit. Richard Nixon would agree. The normalization of relations between the United States and the People's Republic of China was a prospect for the first time in twenty years. On July 15, both nations made the announcement. ${ }^{26}$

Kissinger immediately set about planning an interim trip, during which the significant details of a communiqué would be prepared in advance of Nixon and Mao's formal negotiations. Returning to China in October, he found a much less harmonious capital. A shakeup in the leadership of the PRC had raised tensions as he set about negotiating the basis of the agreement. Kissinger reflected on his negotiations with Chou:

I soon found that the best way to deal with him was to present a reasonable position, explain it meticulously, and then stick to it. I sometimes went so far as to let him see the internal studies that supported our conclusions. Chou acted the same way; the suicidal method was sharp trading. On one occasion when negotiating the Shanghai Communiqué I objected to two sentences in the section of the communique explaining the Chinese point of view. Though we were not responsible for what the Chinese said, I thought that it would lead to controversy in a joint communiqué. I offered to give up two sentences in the section stating the American position in return. "Give your two sentences to your President if you wish," said Chou impatiently. "I do not want them. You do not have to trade; all you have to do is to convince me why our language is embarrassing." He was as good as his word; the most egregious passages disappeared. ${ }^{27}$

At the outset, Kissinger proposed a relatively bland, formal unified statement on the shared positions of both nations. In return, he left the statement of a position on Taiwan blank to signal a willingness to shift the American position in order to find agreement with the PRC. Chou's reply was a firm rebuke. He demanded that each side state its positions, both common and conflicting, on key issues. Stunned at first, Kissinger realized that Chou's demand would not substantively alter either side's position going forward, but could limit internal dissent from hardliners. Kissinger later remarked on the unprecedented structure of the Shanghai Communiqué, completely unlike the relatively anodyne joint statements that often followed U.S.-Soviet meetings:

[The\} Shanghai Communiqué ... was to provide a road map for Sino-American relations for the next decade. The Communiqué had an unprecedented feature: more than half of it was devoted to stating the conflicting views of the two sides on ideology, international affairs, Vietnam, and Taiwan. In a curious way, the catalogue of disagreements conferred greater significance on those subjects on which the two sides agreed. .. . Stripped of diplomatic jargon, these agreements meant, at a minimum, that China would do nothing to exacerbate the situation in Indochina or Korea, that neither China nor the United States would cooperate with the Soviet bloc, and that both would oppose any attempt by any country to achieve domination of Asia. Since the Soviet 
Union was the only country capable of dominating Asia, a tacit alliance to block Soviet expansionism in Asia was coming into being. ${ }^{28}$

Four months later, Nixon and Kissinger followed the preliminary meeting with a five-point statement on Taiwan, setting the stage for Nixon's state visit. Arriving in Beijing in late February, Nixon and Kissinger proceeded to the residence of Mao Zedong, and were greeted effusively by the ailing leader. Speaking in circuitous parables, questions, and statements, Mao invited negotiation with Nixon, signaling that no further agreement would be needed than the visit itself, should an agreement fail to be reached. In the long term, he conveyed, the two nations would draw together.

In the ensuing negotiations, Nixon and Mao talked extensively, educating one another about each other's positions, while leaving the detailed negotiations to Kissinger and Zhao. Within days, the Shanghai Communiqué was finally agreed upon, stating each side's positions, an agreed position, and a way forward on Taiwan. ${ }^{29}$

In five points, the United States pledged to support a unified China with Taiwan, significantly reduce support for Taiwanese independence groups, gradually reduce U.S. military personnel in Taiwan, and encourage regional peace and security. ${ }^{30}$ Moreover, both sides agreed to open formal diplomatic ties, and to avoid the pursuit of regional hegemony at all costs. ${ }^{31}$

Kissinger later wrote that, "[d]espite occasional tensions, the Shanghai Communiqué has served its purpose." 32 Nixon's visit and the communiqué succeeded in achieved Kissinger's immediate goals, linking an agreement on Taiwan to a tacit agreement by the Chinese to cease supporting the North Vietnamese. Both sides stood to gain by checking the aggression of the Soviet Union, and by doing so in a way that de-escalated a growing military crisis.

Not without its costs, the agreement necessitated an uncomfortable reorientation of American and Chinese interests away from allies in order to pursue long-term stability, and that stability remains tenuous four decades later. Nevertheless, Kissinger could confidently reflect that his efforts had a substantial long-ranging effect on relations between two of the world's largest nations. ${ }^{33}$ The opening of China was, he later wrote, "one of the few occasions were a state visit brought about a seminal change in international affairs. The reentry of China into the global diplomatic game, and the increased strategic options for the United States, gave a new vitality and flexibility to the international system." 34

\section{Negotiating SALT I Within Détente}

On January 20, 1969 Henry Kissinger assumed the post as National Security Advisor. That afternoon, President Richard M. Nixon had been sworn in to his first term. The task of crafting American national security policy was now Kissinger's responsibility. Of the many issues before him, nearly all connected to the bitter, decades-long ideological tensions between the United States and the Union of Soviet Socialist Republics (USSR). Epitomized by the nuclear arms race, the Cold War imperiled all of human existence. As Kissinger reflected on the challenges ahead, the Soviets unexpectedly seemed to signal a willingness to begin negotiations on the mutual reduction of nuclear arsenals. For the first time in a generation, a Strategic Arms Limitation Treaty (SALT) appeared to be conceivable. ${ }^{35}$ It would fall to Kissinger to make it a reality. 
Negotiating SALT was an unprecedented opportunity and also an unenviable task. Over the preceding years, the United States had slipped behind the USSR in the arms race. In 1967, President Lyndon Johnson's administration had imposed a cap, limiting the American arsenal to 1054 Intercontinental Ballistic Missiles (ICBMs) and 656 Submarine Launched Ballistic Missiles (SLBMs) ${ }^{36}$ Research and development for new weapons systems continued, but most projects would take years to produce tangible results. Out of concern that a Soviet strike could eliminate the potential for a counter-attack, the United States continued to develop defense systems, specifically Anti-Ballistic Missile Defense Systems (ABMs), but little else. While American weapons production stalled, the Soviets deployed new weapons at a growing pace. ${ }^{37}$ It was evident to Kissinger that the Soviet arsenal could soon surpass the American one.

How to deal with the growing disparity remained a contentious issue within the government. Liberal leaders demanded that the United States unilaterally draw down its existing stockpiles of weapons and cancel expensive research and development programs. By contrast, conservatives and military leaders sought rapid expansion of the U.S. arsenal. ${ }^{38}$ The dichotomy between the two sides reflected a larger Cold War political dynamic.

In late 1949, the Soviets had broken the American nuclear monopoly, succeeding in producing an atomic bomb, precipitating the arms race. Thereafter the relationship between the two powers had been characterized by the wholesale creation of weapons stockpiles and an escalation of tensions amidst a global standoff between both sides' proxies and allies. ${ }^{39}$ Jockeying directly and indirectly for influence with other countries, the standoff sometimes exploded into open warfare, as in the case of the Korean War (1950-53), which claimed millions of lives. ${ }^{40}$

By 1969 the distance and communication gap between the Soviets and Americans was so great that Kissinger remarked, "We had no good evidence concerning the attitudes of Soviet leaders [...] and the distribution of power within the Soviet leadership." 41 He believed that a new way forward was needed, even if it meant going against prevailing wisdom, but the United States was in a difficult position.

Providing massive arms supplies to the North Vietnamese, the Soviets were contributing to a costly military quagmire in Southeast Asia that had radically destabilized the American political and social landscape at home. ${ }^{42}$ Soviet support for Egypt threatened American allies and strategic energy interests in the Middle East. Moreover, each year the United States Congress reviewed the defense budget, including financial appropriations for nuclear weapons. With a Republican president in power, the Democratic-controlled Congress appeared eager to cut the budget one program at a time, tying Nixon's hands as he contemplated negotiations. Kissinger believed that there was only a small window of time to negotiate before Congress began to defund programs needed for bargaining with the Soviets. ${ }^{43} \mathrm{He}$ also feared that the United States' was increasingly limited in its ability to counter a powerful Soviet advance.

In the face of these challenges, Kissinger proposed a deceptively simple strategy to Nixon. Unlike previous administrations, the United States would no longer rely on sending signals to the Soviets through unilateral actions, belligerent or otherwise. Nor would policies focus on influencing the internal power structure of the Soviets in order to gain advantage. ${ }^{44}$ Instead, the United States would engage in a policy of détente; a systematic attempt to reduce tension between the U.S. and Soviets. To do so, the United States would pursue concrete agreements on a range of substantive issues at once. "The Soviet leadership," he later wrote, "would find the new Administration prepared to negotiate lasting settlements reflecting real interests." 45 
Kissinger recognized that the Soviets had little desire to help the Americans find peace in Vietnam or reduce the threat of energy instability caused by ongoing disputes in the Middle East. Yet there were other issues where he saw that settling particular disputes was possible and could create opportunities for progress on negotiations that were deadlocked. He called this approach "linkage." 46 Visiting and re-visiting the possibility for openings on various fronts, and using linkage to advance détente, Kissinger believed the United States could effectively deal with the Soviets. ${ }^{47}$

Within weeks of the Soviet overture on SALT, Kissinger replied to his counterparts, Soviet Foreign Minister Andrei Gromyko and Ambassador Anatoly Dobrynin, but their response was cool and cautious. ${ }^{48}$ Their apparent willingness to negotiate increasingly seemed to have been an attempt to sow discord among the Americans. In reality, fearful that a failed resumption of talks might encourage Nixon initiate a renewed U.S. commitment to producing weapons, the Soviets were concerned that an arms escalation would destabilize their already economically weakened government. In Kissinger's view, they had paid a price for their gains abroad and might benefit from agreements that would reduce higher long-term spending and bring much-needed revenue into their treasury.

In the face of Soviet reluctance, Kissinger pursued SALT, spearheading a newly created presidential panel on arms reduction in order to consolidate control over his many disparate and often disruptive American counterparts. He had frequent back and forth exchanges with Dobrynin and Gromyko. ${ }^{49}$ A round of preliminary talks followed in November, 1970 in Helsinki, Finland, with the purpose of clarifying the two sides' positions. ${ }^{50}$ The communication between both sides was encouraging, but Kissinger believed that firm proposals for an agreement continued to be too elusive.

Kissinger wanted an agreement to limit or freeze production and deployment of existing weapons and defense systems for five years, in part to allow the United States to develop new technologies and eliminate any Soviet military advantage. The Soviets wanted an agreement only on defensive Anti-Ballistic Missile Systems, so that they could continue to deploy offensive weapons. Kissinger refused, but faced a significant problem. ${ }^{51}$ The Soviets would not negotiate both issues in tandem, but wanted to negotiate ABMs first so that they could reach an agreement and then stall subsequent negotiations over offensive weapons production. After months of negotiating, Kissinger was able to get a Soviet agreement to consider negotiating the two issues as a de facto package in close proximity. ${ }^{52}$ From there, the conversations stalled yet again, delayed by the Soviets, who felt that they could wait him out while U.S. domestic pressure built for "progress." 53 Even repeated attempts to arrange a date for a substantive negotiating summit proved elusive. Kissinger recognized that a different approach was needed.

In order to reach a satisfactory agreement, Kissinger began looking for issues of interest to the Soviets, for the purpose of linking them back to the SALT talks in ways that might precipitate movement. Where the United States was weakened by Vietnam and had only precarious access to key foreign oil sources, the Soviets were in desperate need of financial stability that could only come from increased trade with Europe and the United States. To Kissinger this meant that the most promising issue to link to SALT appeared to be the long-simmering dispute between the Soviets and the western Allies over the status of Germany. ${ }^{54}$

Following the end of World War II, the four Allied powers - America, the Soviet Union, France, and Britain-maintained military control over Germany. In the subsequent decade, a democratic 
West German state emerged alongside a pro-communist, Soviet-backed East German state, and tensions quickly grew between the two. Berlin became the focus of these hostilities. ${ }^{55}$

To ensure security, the three non-Soviet powers retained military control over West Berlin while East Berlin was walled off by the Soviets. As a military protectorate, West Berliners were not recognized as citizens of the Bonn-based Federal Republic of Germany. ${ }^{56}$ Throughout the 1960s, with Berlin surrounded and supported by endangered supply lines, the West Germans and Allies refused to settle significant territorial disputes and wartime claims with the USSR. In turn, without a settlement, the Soviets' ability to trade with the Allies was severely restricted.

In 1969, West German Prime Minister Willy Brandt began a concerted effort to break the impasse with the East, proposing a series of treaties focused on reducing tensions by opening trade agreements, resolving disputed territorial claims, clarifying military arrangements, largely in an effort to keep the future possibility of a unified German state alive. ${ }^{57}$ Brandt's Ostkpolitik would earn him the Nobel Peace Prize, but as Kissinger looked to dislodge the Soviets from their position on SALT, the United States opposed Brandt's strategy. Now Kissinger realized that it could be time to carefully lift American opposition to Ostpolitik, reaching an accord on the status of Berlin, ways to supply it, and possibilities to open trade with the East. ${ }^{58}$

Negotiating quietly with Dobrynin, Kissinger created a back channel in order to test ideas and agreements and prevent disruption from other senior Nixon administration officials, especially William Rogers' State Department. ${ }^{59}$ Only U.S. Ambassador Kenneth Rush, West German minister Egon Bahr, and Soviet Ambassadors Valentin Falin and Pyotr Abrasimov knew of the private discussions. Once items were settled in this back channel, these interlocutors would formally introduce them in public talks on Berlin. The "Channel," as it came to be known, was quite effective. The Soviets proved eager to negotiate on Berlin and West Germany, quickly seeking agreement and displaying a willingness to discuss SALT in return. Throughout the spring of 1971, the two sides negotiated ways to reach agreement while saving face, crafting solutions like granting West German passports to West Berliners in lieu of fully recognizing the territory as part of the Federal Republic. ${ }^{60}$

Yet there were setbacks to Channel negotiations. In May, 1970, without sufficient trust between the two sides, the Soviets attempted destabilize Kissinger's position by having Abrasimov reveal back channel matters during open negotiations. Kissinger was furious. Confronting Dobrynin, he warned that Nixon preferred the back channel and would be enraged by their actions. As a punishment, he slowed negotiations at a critical moment, refusing to communicate with the Soviets to prove the point. If the Soviets tried it again, he told them the Americans would stop negotiating on Germany. ${ }^{61}$

By early summer, the negotiations were once again on track and an agreement looked increasingly likely. The Soviets seemed eager, ceding most points on the status of Berlin. Yet when secretly agreed terms from the Channel were surfaced openly, U.S. officials treated the proposal as a starting place for negotiation, unaware that they were modifying a settled agreement. Kissinger and Dobrynin swiftly intervened, halted the negotiations, and reintroduced the Channel agreement, which was signed in September 3, 1971. Reaching the agreement, however, meant that Kissinger had to reveal the existence of the Channel to his U.S. Government counterparts.

Indirectly related to SALT, the Berlin negotiations became a significant parallel track that had a noticeable impact on accelerating substantive nuclear arms talks. "Linkage was working," Kissinger reflected, "only amateurs believe in one-sided deals." 62 As the Berlin track of negotiations proceeded, more progress could be made on SALT. 
By the summer of 1971, the Berlin talks had helped nudge the Soviets to agree to the de facto package, negotiating an offensive nuclear weapons treaty slightly prior to an ABM treaty. A summit was now needed in order to resolve three significant remaining issues: the duration of SALT's effectiveness, the number of SLBMs the Soviets would be required to dismantle, and the number of ABMs to be allowed. All of these required face-to-face negotiations. With each success on the German track, Kissinger urged the Soviets to set a summit date, but believing they had the, the Soviets stalled instead, steadfastly refusing to arrange a Moscow meeting. ${ }^{63}$

In mid-July, the Soviets replied to Kissinger's most recent request for a summit date by making two demands while continuing to withhold a date. They told him that the United States must reach agreement on Berlin and must demonstrate a willingness to reduce tensions. ${ }^{64}$ They did not know that Kissinger was in Beijing, preparing to reach an historic agreement to restore relations with the Chinese. When he replied to the new Soviet demands, it was thirty minutes before his public announcement of success in China. He told the Soviets that he had met their demands. An agreement on Berlin was coming, and now the United States was beginning to normalize relations with China, a significant counterpart, in order to de-escalate hostilities. It just so happened that the China deal threatened Soviet dominance. Kissinger had introduced China as yet another link; in short order, the Soviets proposed a date for the summit for the following year. ${ }^{65}$

In the spring of 1972, Kissinger travelled to Moscow to prepare for the summit. For the first time he met directly with Soviet Premier Leonid Brezhnev, who had emerged from a power struggle as the most senior of the Soviet Union's powerful governing troika. To Kissinger's surprise, Brezhnev agreed to a five-year treaty, a reasonable negotiation of ABMs and the same limit on SLBMs as Kissinger's team had initially hoped to negotiate. As Kissinger departed for home, Brezhnev even provided him with a formal statement reiterating the basic framework for the May 23 Moscow summit. 66

Kissinger returned to the United States having advanced the SALT negotiations to a final round. Using the Channel, he had consolidated bureaucratic and political control of the negotiations on the U.S. side, managing the flow of critical information through his own team and crafting proposals outside of conventional thinking while maintaining a close connection with the President Nixon. In so doing, he prevented others, especially his rivals in Congress, political opponents, and Secretary of State Rogers from upsetting the delicate links he had forged between each set of issues. Increasingly, he was free to make decisions without intervention, even when his decisions raised alarm among fellow foreign policy officials and domestic constituencies. ${ }^{67}$

The negotiation of SLBMs was perhaps most emblematic of Kissinger's freedom within the process. To many within the American foreign policy leadership, he appeared to make a terrible blunder early in negotiations with the Soviets, accepting the notion of a provision for freezing the production of offensive SLBMs. Senior American military leaders were appalled, because they saw the production of SLBMs as vital. In actuality, Kissinger had made no mistake at all.

The Soviets were deploying one hundred new SLBMs each year. The United States was not deploying any. With a new SLBM program in development, the United States would not be able to deploy new weapons until 1978, one year after agreed end date of the treaty. Where others saw a miscalculation, Kissinger realized that, "for [the United States] the sacrifice was theoretical," and the gain was significant. ${ }^{68}$ The United States would fall no further behind the Soviets in the production of actual armaments, while retaining the right to plan the development of new weapons that could be built after the expiration of SALT. ${ }^{69}$ 
Negotiating in Moscow, agreement was steadily reached on the freezing of ICBM development, dismantling of SLBMs and other weapons, and a limitation on ABMs. As agreed, the treaty would last for five years. All that remained was agreement on limiting the size of missile silos. At a critical moment, Kissinger reminded his Soviet counterparts that any delay would go against the previously expressed views of their own Premier. Brezhnev had asked that the negotiations conclude by May 26. The last impasse was quickly surmounted and an agreement on SALT was reached in time for a Soviet state dinner on Friday, May 26, 1972.70

In a negotiation lasting over two and a half years, Kissinger created potential for a deal by allowing the implicit threat of increased U.S. arms production to persist while linking SALT to negotiations in over trade, the status of Germany, and relations with China where none had previously existed. There were certainly drawbacks to his approach. He later reflected that the process, especially the Channel was imperfect. It freed him from the cumbersome, overlyideological, and slow-moving bureaucracy of government, but also placed a large burden on him and his staff, and made it difficult for him to gain the support-or potentially useful perspectives-from other government officials on matters that ultimately required public, official assent. ${ }^{71}$

Yet the outcomes also affirmed the success of his efforts. SALT I was a defining agreement of the Cold War and one of the most significant disarmament treaties in modern history. Its stipulations ultimately paved the way for future treaties on nuclear disarmament, including SALT II, an agreement signed by President Jimmy Carter in 1979, though not ratified by the U.S. Congress, banning most new missile production by the United States and the Soviet Union. ${ }^{72}$

Kissinger's approach to linkage and the resulting SALT agreement generated significant opposition both among conservatives and liberals in the United States, but achieved the fundamental aims of détente. As a result, his actions reconfigured a previously unsuccessful American foreign policy that had been mired in recriminations over Vietnam, redefined black and white conceptions that had dominated U.S.-Soviet as well as U.S. Chinese relations, and froze substantial Soviet weapons development. Kissinger could reflect that, "Never before have the world's two most powerful nations, divided by ideology, history and conflicting interests, placed their central armaments under formally agreed limitation and restraint." 73 These actions, set in motion by SALT and Berlin, and boosted by the Nixon-Kissinger Chinese initiative, set the stage for the United States ultimately to take a dominant role in ending the Cold War. ${ }^{74}$

\section{Sinai I and Mideast Peace}

In October 1973, Egyptian and Syrian forces launched a full-scale military attack against Israel six years after their humiliating defeat in the 1967 War. Caught by surprise on Yom Kippur, the holiest day of the Jewish year, Israeli forces were steadily pushed back from their positions. Many Israelis feared the destruction of their state before their armed forces regained ground and defeated both Arab armies. In the east, Israeli troops reached the outskirts of the Syrian capitol, Damascus. In the west, they surrounded Egypt's entire Third Army, only 101 kilometers from Cairo. By the end of the month, two resolutions passed by the United Nations Security Council resulted in a ceasefire. Egyptian and Israeli generals met at the front to discuss disengagement. For both sides the war was a partial victory at best: partially redeeming their near-total defeat in the 1967 war, the Arab armies had surprised Israel and inflicted heavy losses while the Israeli counterattack eventually prevailed. ${ }^{75}$ For Henry Kissinger, U.S. Secretary of State, this situation presented a major opportunity. ${ }^{76}$ 
Following the ceasefire, multi-party talks convened in Geneva to hammer out a long-term solution to the Mideast conflict. Egyptian and Israeli negotiators were joined by their Cold War patrons, the Soviet Union and the United States, but Syrian leaders refused to participate and the talks collapsed in early January $1974 .{ }^{77}$ Kissinger had correctly anticipated that multi-party talks would fail. Since early November, he had believed that an agreement for long-term stability in the region was possible only if the United States single-handedly brokered small, meaningful, incremental agreements between the Israelis and Egyptians. ${ }^{78}$ Prepared to take the precarious role of sole mediator, Kissinger planned to use the process not only to reach agreements among the combatants, but to achieve a major geopolitical objective: to displace the Soviet Union from its Middle Eastern sphere of influence. Until the outbreak of war, the Soviets had used the years-long stalemate between the Arabs and Israelis to cultivate alliances with Arab nations, encouraging a status quo that effectively blocked the United States from gaining influence in the region. The war had suddenly dislodged the Arabs and Israelis from their positions. In its wake, Kissinger sensed an emerging opportunity if he could successfully pursue an agreement that largely met both sides' interests. He later explained

If the United States played its cards carefully, either the Soviet Union would be obliged to contribute to a genuine solution or one of its Arab clients would break ranks and begin moving toward the United States. In either case, Soviet influence among the radical Arab states would be reduced. This was why, early in Nixon's first term, I felt confident enough to tell a journalist that the new administration would seek to expel Soviet influence from the Middle East. Though that incautious remark created a furor, it accurately described the strategy the Nixon Administration was about to implement. ${ }^{79}$

Kissinger's optimism about realizing these audacious goals was based on a careful assessment of each side's strengths and weaknesses. Israeli Prime Minister Golda Meir and Egyptian President Anwar Sadat were powerful and effective leaders and both had made gains in the October war. Despite the subsequent losses, Sadat showed that he was the de facto leader of the Arab Middle East, capable of coordinating a multinational military assault that unified Arab nations, catching the Israelis entirely by surprise. In turn, Meir proved that Israel could defeat its enemies and even gain territory in the face of such a stunning initial setback. Israel now held the entirety of the Sinai desert, which had belonged to Egypt until the 1967 war. Despite these successes, Kissinger knew that both sides had emerged from the war in precarious positions.

The Israelis prided themselves on a robust policy of pre-emptive warfare, and were deeply shaken by the effectiveness of the Syrian and Egyptian surprise attack. Sadat had lost vital territory, and needed to grapple with issues that facing the long-term stability of a nation already beset upon by significant economic difficulties. Humbled by the inconclusive outcome, both sides faced longterm unrest within and across their borders, unless they could arrive at a diplomatic easing of relations.

In a moment of crisis following the war, Golda Meir's formerly powerful government coalition collapsed. A new government and parliament (Knesset) would take office at the end of January. Often comprised of unstable coalitions, Israeli cabinets were notoriously unstable and difficult to work with, but Kissinger observed that during times of transition, factionalism might give way to near-unanimity on significant issues. If the Israelis could be induced to make an offer on Sinai disengagement, he believed that Sadat would agree in the interests of long-term stability. ${ }^{80}$ 
Meeting with Israeli Defense Minister Moshe Dayan, Kissinger explored the possibility of an Israeli disengagement proposal. Dayan obliged, offering a hard line proposal, but one that Kissinger felt he could deliver to Sadat, albeit uncomfortably, in order to determine whether the Egyptian President would be amenable to further talks. ${ }^{81}$ Arriving at Sadat's winter residence in Aswan late in the evening on January 11, he was quickly ushered in to meet with the President. Little more than two months earlier, Kissinger had set foot on the soil of an Arab nation for the first time. ${ }^{82}$ Now, he and the Egyptian president spoke frankly with one another. Weeks earlier in Geneva, Sadat had hinted that if presented with a suitable agreement, he might go so far as re-opening the long-closed Suez Canal, a major concession to the Israelis. Now, he was prepared to do even more. ${ }^{83}$

Beyond a disengagement proposal, Sadat told Kissinger that he intended to travel internationally on the 18th of January. He hoped to have a diplomatic victory in hand and to link it to his initial military success in the October war. He told Kissinger that he would support every effort to reach an agreement in just seven days, and hoped the Secretary of State would act as the intermediary. In return, he offered to pressure Arab leaders to ease their oil embargo of the United States, begun during the October war. ${ }^{84}$

Kissinger was surprised, pleased, and wary all at once. He later reflected, "In my view, the Secretary of State should not, as a general rule, go abroad on a serious negotiation unless the odds are heavily in his favor. Since in diplomacy the margins of decisions are narrow, the psychological element can be of great consequence. A reputation for success tends to be self-fulfilling. Equally, failure feeds on itself: A Secretary of State who undertakes too many journeys that lead nowhere depreciates his coin. And it is dangerous to rely on personality or negotiating skill to break deadlocks; they cannot redeem the shortcomings of an ill-considered strategy." 85 Despite the risks, the window of opportunity was too great. Kissinger accepted Sadat's proposal.

Kissinger returned to Israel with Sadat's offer in hand. In return he requested that the Israelis make a new proposal, more forthcoming than Dayan's original demands. The Israelis obliged, but handed Kissinger an even more austere proposal, telling him that the Dayan plan could be their fallback position. Kissinger was not amused. He argued that any proposal that could not be sold to a nation's people should not be seriously proposed to their leader. Access to Sadat, without the impediment of intermediaries, was already a concession. He would convey either side's proposals honestly, but he would not be set up to fail and be blamed. ${ }^{86}$

Returning to the Tel Aviv airport, Undersecretary of State Joe Sisco joked with Kissinger, "Welcome to the Egyptian-Israeli shuttle!" 87 Shuttle diplomacy, in which a negotiator moves back and forth between parties who will not or cannot meet face-to-face, ensued. Kissinger used the shuttle to create momentum for an agreement. He arrived late in the evening, often intentionally too late to negotiate, worked even later into the night, presented plans early in the mornings, and indefatigably wrote, revised, and redrafted proposals and agreements. ${ }^{88}$ He encouraged a sense of momentum to develop between the parties, pushing beyond exhaustion, seeking the exact moments to withhold and reveal each side's demands and concessions. Focused on details as minute as individual troop placements, Kissinger even delayed landing his plane in Egypt while he worked, circling above the airport, to ensure the proper preparation of a proposal. ${ }^{89}$

Fearful of any disruption, Kissinger sometimes even kept the White House at bay. When President Nixon, embattled by the Watergate scandal, got word that an agreement might be close, he requested that Kissinger return to the United States in order to publicly announce the potential impending agreement. Kissinger refused, telling the President that he would not leave until an agreement was signed. ${ }^{90}$ 
As he travelled back and forth, Kissinger also steadfastly maintained an eye on his own standing. The fact that October war had ended in need of a diplomatic outcome-rather than in a bloody fight to the finish - was testament to the success of détente, which had curtailed military support from the Americans and Soviets to the Israelis and Egyptians respectively. Now Kissinger used the shuttle and the weakened ties between the Soviets and Egyptians to dislodge the U.S.S.R. completely from that part of the region. He avoided arousing undue suspicion by sending non-descript updates to the Soviets by way of a senior national security aide, Brent Scowcroft. ${ }^{91}$

As January 18th neared, Kissinger narrowed the terms of an agreement. Both sides made significant concessions and a final proposal emerged. Egypt gained concessions to retain troops east of the Nile. Israel maintained control of the only major north-south road from its territory into the Sinai. Both sides agreed to an uneasy $30 \mathrm{~km}$ buffer zone, nearly out of easy striking distance for either military. ${ }^{92}$

With documents shuttling back and forth in the hands of the Secretary of State, both sides allowed Kissinger to arrange two tracks of agreement. A formal, detailed document was developed for both sides to sign. Simultaneously, Kissinger secured Nixon's agreement to draft letters to both sides confirming Israeli and Egyptian commitments to significant concessions that could not be fully detailed without both sides losing face with their own constituencies. ${ }^{93}$ Most importantly these included an Egyptian willingness to clear the Suez Canal and an Israeli agreement to reduce or cease hostilities. ${ }^{94}$

On January $17^{\text {th }}$, Kissinger arrived in Jerusalem during the first snowfall in decades. ${ }^{95}$ He went to Golda Meir's residence with a proposal, approved by her cabinet. The ailing Prime Minister promised to take the agreement to conclusion personally and drafted a letter of gratitude to her Egyptian counterpart. For the first time in two decades, Israel had ceded land for peace. ${ }^{96}$

The next morning, seven days after Sadat's ultimatum, Kissinger delivered the agreement at Aswan while representatives of both governments signed it at the 101 kilometer marker where the war had ended. Reading Meir's letter, Sadat turned to Kissinger saying, "I am today taking off my military uniform - I never expect to wear it again except for ceremonial occasions. Tell her [Golda] that is the answer to her letter." 97

Significant issues remained unresolved, most importantly an agreement for formal cessation of hostilities between Israel and Egypt. Yet the Sinai accords set in motion a series of agreements and commitments between Israel and Egypt that continued over the ensuing six years. Undertaken at significant cost, sometimes with deep misgivings, those agreements would directly lead to the assassination of Sadat in 1981. Despite the evident threat to their lives as they proceeded, they did so nonetheless, at many points affirming Kissinger's initial inclination that peace could be found, and culminating half a decade later with the 1978 Camp David Accords and the 1979 Egypt-Israel peace treaty.

\section{Appendix 1: Selected Negotiations}


Henry Kissinger played key roles in many important diplomatic negotiations, a selection of which are very briefly described below. ${ }^{\text {a }}$

\section{Détente}

Détente is the easing of political and military tensions between the Union of Soviet Socialist Republics (USSR) and the United States of America. The policy gained prominence in 1969 as an explicit strategy employed by Henry Kissinger and Richard Nixon to address the nuclear weapons stalemate between both countries. During Kissinger's time as National Security Adviser and Secretary of State, the doctrine of détente formed the philosophical underpinning for the strategies that resulted in the SALT I and ABM treaties, the Helsinki Accords, and other significant agreements between the United States and USSR.

SALT I, 1972 (see above)

ABM Treaty, 1972

Originally negotiated as part of the preliminary talks which led to the SALT I agreement, the Anti-Ballistic Missile (ABM) treaty was ultimately separated from the larger agreement as a strategic concession in order to circumvent significant impediments to an overarching arms reduction agreement. Nevertheless, Kissinger negotiated the ABM in a roughly parallel fashion with SALT, reaching an accord with the USSR to limit both nations to two Anti-Ballistic Missile complexes with limitations of $100 \mathrm{ABMs}$ per site.

China, 1971-2 (see above)

\section{Helsinki Accords}

A series of significant agreements on wide-ranging issues of importance between the USSR, the United States, and nearly three dozen European states, the Helsinki Accords were the result of a significant long-running series of incremental forums and agreements begun in 1969. Directly a result of the Conference on Security and Cooperation in Europe (CSCE) negotiations, the Accords, which were reached after a month-long negotiation from July 1-August 1, 1975. Though not a binding treaty, the Helsinki Accords addressed a substantial number of military, economic, political, and human rights disagreements between the Eastern Bloc of Soviet-aligned nations and the participant members of NATO.

\section{Paris Peace Accords}

The Agreement on Ending the War and Restoring Peace in Vietnam was signed by Democratic Republic of Vietnam (North Vietnam), the United States, and The Republic of Vietnam (South Vietnam) on January 27, 1973, officially ending the costly American military involvement in Vietnam. Intended to result in a peaceful cessation of hostilities, the accords were followed by the Case-Church Amendment, passed by the United States Senate later that year. Two years later, the accords would fall apart amidst the North Vietnamese invasion of South Vietnam, which culminated in the withdrawal of American support for the South and the collapse of the South Vietnamese government in the spring of 1973.

a A full list of Kissinger's negotiations can be found in his three-volume biography: White House Years (1979), Years of Upheaval (1982), Years of Renewal (1999). 
Yom Kippur War Ceasefire (see above)

\section{Sinai II}

The Sinai Interim Agreement was signed by Egypt and Israel on September 4, 1975 in Geneva. The agreement reinforced the significant, largely symbolic concessions that formed the basis of the Sinai I agreement, reached in the wake of the 1973 Yom Kippur War (see body text above). The Sinai Interim Agreement further strengthened the provisions of the Sinai I agreement, affirming Israel's intent to cede further territory that had been seized from Egypt during the Yom Kippur War. The agreement directly set the stage for the Camp David Accords, a sweeping peace agreement between Israel and Egypt, reached three years later. However, the Sinai Interim Agreement also angered significant constituencies in the Arab and Israeli worlds, leading to future discord, and the assassinations of Egyptian President Anwar Sadat as well as Israeli Prime Minister Yitzhak Rabin.

\section{Nonproliferation Negotiations with Israel, South Korea and Pakistan}

An ardent believer in the importance of nonproliferation of nuclear weapons, Kissinger expressly undertook efforts to hinder the development and proliferation of nuclear weapons across the globe. Both as National Security Adviser and Secretary of State, Kissinger confronted Israeli, South Korean, and Pakistani leaders, opposing their attempts develop weapons. To do so, Kissinger employed all efforts at his disposal including sanctions, offers of incentives, and even threats to remove U.S. military protection for allies.

\section{Panama Canal Negotiations}

Disagreement between the United States and Panama over future control of the Panama Canal culminated in a growing diplomatic crisis between the two nations in the early 1970s. At issue was an agreement on terms that would satisfactorily transfer control of the Canal Zone to Panama, while guaranteeing certain future rights of passage for the United States. In 1974, Kissinger and Panamanian Foreign Minister Juan Antonio Tack agreed to a set of principles that would guide subsequent negotiations, and ultimately the agreement of a timeframe for transfer of the canal. Negotiated in subsequent years, the United States and Panama reached an agreement in 1977. 


\section{Endnotes}

${ }^{1}$ Office of the Historian, "Biographies of the Secretaries of State: Henry Alfred Kissinger. " Washington, D.C.: Department of State. http:/ / history.state.gov/departmenthistory/people/kissinger-henry-a. Accessed Nov, 2014

2 “Henry A. Kissinger: Biography,” 2014 http:/ / www.henryakissinger.com/biography.html. Accessed Nov. 2014.

${ }^{3}$ Isaacson, Walter. Kissinger: A Biography. New York: Simon and Schuster. 1983.

${ }^{4}$ Henry A. Kissinger: Biography

${ }^{5}$ Office of the Historian. "A Short History of the Department of State: Kissinger Becomes Secretary of State." Washington, D.C.: Department of State. https://history.state.gov/departmenthistory/short-history/kissinger. Accessed Nov. 2014

6 "Biographies of the Secretaries of State"

7 “Henry Kissinger: Facts.” Nobelprize.org. Nobel Media AB 2014. Web. 18 Nov 2014.

<http://www.nobelprize.org/nobel_prizes/peace/laureates/1973/kissinger-facts.html>

8 "Henry Kissinger - Biographical". Nobelprize.org. Nobel Media AB 2014. Web. 17 Nov 2014.

<http://www.nobelprize.org/nobel_prizes/peace/laureates/1973/kissinger-bio.html>

${ }^{9}$ Kissinger, Henry. The White House Years. Boston: Little Brown, 1979.

${ }^{10}$ Kissinger, Henry. Diplomacy. New York: Simon \& Schuster, 1994

${ }^{11}$ Kissinger, Henry A. On China. New York, NY: Penguin Press. 2011.

12 Kissinger, Henry A. World Order. New York, NY: Penguin Press. 2014.

13 On China, p. 237.

14 On China, p. 238.

15 On China, p. 223.

${ }^{16}$ Diplomacy, p. 772.

${ }^{17}$ White House Years, p. 685.

18 White House Years, p. 166

${ }^{19}$ Strategic Survey, The Sino-Soviet dispute. International Institute for Strategic Studies: Volume 70, Issue 1, 1969: 66-72; 100-02.

${ }^{20}$ White House Years, pp. 684-93.

${ }^{21}$ On China, pp. 225-6.

22 On China, pp. 230-1.

23 On China, pp. 233-4.

24 White House Years, p. 740.

25 On China, p. 249.

${ }^{26}$ White House Years, pp. 758-59.

27 White House Years (Kindle Edition), location: 15428.

28 White House Years (Kindle Edition), Locations: 13670, 13678.

${ }^{29}$ White House Years, pp. 1084-87.

${ }^{30}$ On China, p. 271.

31 On China, p. 270. 
32 On China, p. 272.

33 On China, p. 272-4.

34 On China, p. 272.

${ }^{35}$ White House Years, p. 132.

${ }^{36}$ White House Years, p. 124.

${ }^{37}$ White House Years, p. 124.

${ }^{38}$ White House Years, p. 124.

${ }^{39}$ Years of Upheaval, pp. 256-62.

${ }^{40}$ Malkasian, Carter. The Korean War. Oxford: Osprey Publishing. 2001. p. 88.

${ }^{41}$ White House Years, pp. 793-94.

42 White House Years, pp. 64-5.

${ }^{43}$ White House Years, pp. 812-13.

44 White House Years, pp. 162, 793-94, 796-97, 798.

${ }^{45}$ White House years, p. 127.

46 White House Years, p. 127-30

47 White House Years, p. 132.

48 White House Years, pp. 150-55, 814.

49 American Foreign Policy, p. 146.

${ }^{50}$ White House Years, p. 810

${ }^{51}$ White House Years, pp. 147-50; 204-12.

52 White House Years, p. 816.

${ }^{53}$ White House Years, p. 814.

${ }^{54}$ White House Years, pp. 528, 529-34.

55 For a fuller analysis see: Keithly, David M.. Breakthrough in the Ostpolitik: The 1971 Quadripartite Agreement. Boulder and London: Westview Special Studies in International Relations. 1986.

56 White House Years, pp. 529-34, 824.

${ }^{57}$ Keithly.; Also see Fink, Carole and Bernd Schaefer. Ostpolitik, 1969-1974. Cambridge: Cambridge University Press. 2009.

58 White House Years, pp. 529-34, 833-34; American Foreign Policy, p. 142.

${ }^{59}$ White House Years, p. 523

${ }^{60}$ White House Years, pp. 830-31

${ }^{61}$ White House Years, pp. 816-19, 829.

62 White House Years, p. 833.

${ }^{63}$ White House Years, p. 553.

64 White House Years, pp. 834-35 
65 White House Years, pp. 834-35, 837.

${ }^{66}$ White House Years, pp. 1131-54.

${ }^{67}$ White House Years, pp. 1154-64

68 Years of Upheaval, pp. 257.

${ }^{69}$ American Foreign Policy, p. 150.

${ }^{70}$ White House Years, pp. 1241-42.

${ }^{71}$ White House Years, p. 805

72 Office of the Historian, “Milestones 1969-76: Strategic Arms Limitation Talks (SALT) I and II. " Washington, D.C.: Department of State. https://history.state.gov/milestones/1969-1976/salt. Accessed Nov, 2014.

73 American Foreign Policy, p. 139.

${ }^{74}$ White House Years, p. 801.

75 Years of Upheaval, pp. 405-66.

76 Years of Upheaval, p. 467.

77 Years of Upheaval, pp. 747-98.

78 Years of Upheaval, pp. 466-7.

${ }^{79}$ Diplomacy (Kindle edition), locations: 13832-3.

${ }^{80}$ Years of Upheaval, p. 800.

81 Years of Upheaval, pp. 800-5.

82 Years of Upheaval, pp. 629-45.

${ }^{83}$ Years of Upheaval, pp. 809-11.

84 Years of Upheaval, p. 811.

85 Years of Upheaval, p. 803.

${ }^{86}$ Years of Upheaval, pp. 815-18.

${ }^{87}$ Years of Upheaval, p. 798.

88 Years of Upheaval, p. 810, 818-21.

${ }^{89}$ Years of Upheaval, pp. 799-853.

90 Years of Upheaval, p. 830, 833.

91 Years of Upheaval, pp. 803-4.

92 Years of Upheaval, pp. 821-853.

93 Years of Upheaval, pp. 832-36.

94 Years of Upheaval, p. 835.

95 Years of Upheaval, pp. 836-7.

96 Years of Upheaval, pp. 837-8, 840-1.

97 Years of Upheaval, pp. 844-6, 844. 


\section{Bibliography}

\section{Books \& Journals}

Fink, Carole and Bernd Schaefer. Ostpolitik, 1969-1974. Cambridge: Cambridge University Press. 2009.

Isaacson, Walter. Kissinger: A Biography. New York: Simon and Schuster. 1983.

Keithly, David M.. Breakthrough in the Ostpolitik: The 1971 Quadripartite Agreement. Boulder and London: Westview Special Studies in International Relations. 1986.

Kissinger, Henry A. American Foreign Policy: Expanded Edition. New York, NY: W.W. Norton, 1974.

Kissinger, Henry A., Diplomacy, New York, NY: Simon \& Schuster, 1994

Kissinger, Henry A. On China. New York, NY: Penguin Press. 2011.

Kissinger, Henry A. White House Years. New York, NY: Simon \& Schuster, (1979).

Kissinger, Henry A. Years of Upheaval. New York, NY: Little, Brown, 1982.

Malkasian, Carter. The Korean War. Oxford: Osprey Publishing. 2001. p. 88.

Strategic Survey, The Sino-Soviet dispute. International Institute for Strategic Studies: Volume 70, Issue 1, 1969: 66-72; 100-02.

\section{Websites}

“Henry A. Kissinger: Biography,” 2014 http:/ /www.henryakissinger.com/biography.html. Accessed Nov. 2014.

“Henry Kissinger: Facts." Nobelprize.org. Nobel Media AB 2014. Web. 18 Nov 2014. <http://www.nobelprize.org/nobel_prizes/peace/laureates/1973/kissinger-facts.html>

"Henry Kissinger - Biographical". Nobelprize.org. Nobel Media AB 2014. Web. 17 Nov 2014. <http://www.nobelprize.org/nobel_prizes/peace/laureates/1973/kissinger-bio.html>

Office of the Historian, "Biographies of the Secretaries of State: Henry Alfred Kissinger. " Washington, D.C.: Department of State. http:/ / history.state.gov/departmenthistory/people/kissinger-henry-a. Accessed Nov, 2014.

Office of the Historian, “Milestones 1969-76: Strategic Arms Limitation Talks (SALT) I and II. " Washington, D.C.: Department of State. https:/ / history.state.gov/milestones/1969-1976/salt. Accessed Nov, 2014.

Office of the Historian. "A Short History of the Department of State: Kissinger Becomes Secretary of State." Washington, D.C.: Department of State. https:/ / history.state.gov/departmenthistory/short-history/kissinger. Accessed Nov. 2014. 